\title{
Some Electrical and Optical Properties of Potassium Dichromate Crystals
}

\author{
Kazuo Marsumoto and Shin Suzuki \\ Department of Printing, Faculty of Engineering, Chiba University; \\ Yayoi-cho, Chiba-shi, Japan
}

\begin{abstract}
Electrical conductivities, absorption spectra and thermally stimulated current of single crystals of potassium dichromate were measured to make clear its electrical and optical properties.

The activation energy of ionic conduction was found to be $1.21 \mathrm{eV}$ along the perpendicular axis to $(11 \overline{3})$ plane.

The fundamental absorption edge of a potassium dichromate crystal along the perpendicular axis to $(1 \overline{2} 0)$ plane was $2.16 \mathrm{eV}$ at $293^{\circ} \mathrm{K}$. Further, it was found that the absorption edge shifted to shorter wavelength, as the temperature decreased.

It was detected by the measurements of thermally stimulated current that the carrier traps were located at $0.46 \mathrm{eV}$ and $0.50 \mathrm{eV}$ below the conduction band along the perpendicular axis to (113) plane. These traps may be anisotropic, since the thermally stimulated current along the perpendicular axis to (120) plane was only slightly observed.
\end{abstract}

\section{トリフルオロ酴酸ニッケルーホルムアミド浴によるニッケルの電析}

(1972 年 4 月 19 日受理)

\author{
武井たつ子・小島 林 平*
}

\begin{abstract}
トリフルオロ酢酸ニッケルーホルムアミド溶液はトリフルオロ酢酸ニッケル淡度の增加にとるない粘度, 比導電亭

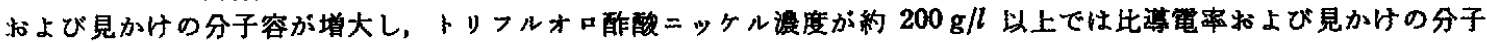
容の値は一定値に近つく傾向を示した。また,トリフルオロ酢酸ニッケルの浇度が高いと溶媒化分解が促進されて沈 殿物を生成するよ5になる。このような溶液の性質から、ニッケル電析浴としてはトリフルオロ酢酸ニッケルの灌度 を $200 \mathrm{~g} / l$ 以下Kするのがよい。

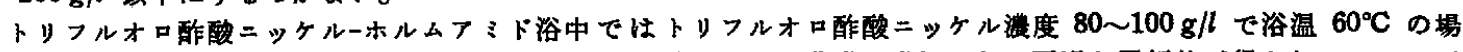
合に電流密度 $0.5 \sim 2.0 \mathrm{~A} / \mathrm{dm}^{2}$ の範囲内で索地との密着性のよい非常に光沢のある平滑な電析物が得られ，カソード 電流効宰は約 90\% で，アノード電流效率は 100\% に近い值であった。低電流密度で得られた良好な䉓着面はごま

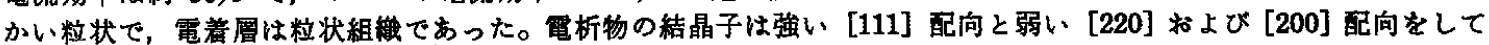
いた。結晶子の大きさは70〜80 $\mathrm{A}$ できわめて小さい。

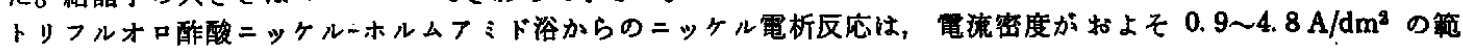

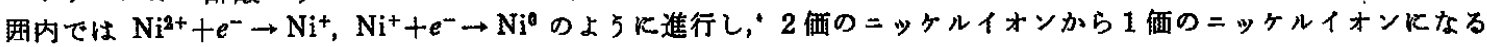
反応が律速になっているすのと考克られる。
\end{abstract}

\section{1 稀 曹}

非本溶液からの金属の電析に関しては，その必要性が Brenner(17)18) あるいは Menzies ら ${ }^{14)}$ によって提唱され，いろいろな

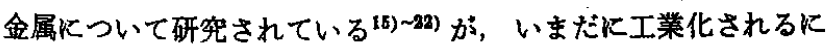
いたっていない。ニッケル電析についてる水溶液の場合は普通浴, ワッッ浴怙よびスルファミン酸浴などがあり，さらに電析の目的 により添加剂が検討され，その作用機構についてす数多くの報 告1)2)がなされている。しかし，非水溶液の場合は塩化二ッヶルー

* 信州大学工学部, 長野市若里

1）金属表面技術協会編，“電気人ッキ技術”，朝会書店(1969) p. 119 .
ホルムアミド浴夺4), キオシアン酸ニッケルーホルムアミド浴(4), 醈 酸ニッケルあるいはへキサアンミンニッケル（II)臭化物を容解し たホルムアミド浴とアセトアミド浴(6), トリフルオロ䣫酸ニッケ ル-塩化アルミニウムーアルコール浴7) などがある程度である。し かむ，これらの研究では有機溶媒に溶解しや寸いニッケル塩およ

2）林 忠夫，金属表面技術 20 周年記念号 (1970) p. 15.

3) H. Röhler, Z. Electrochem., 16, 419(1910).

4) R. D. Blue, F. C. Mathers, Trans. Electrochem. Soc., 63,231 (1933).

5) L. F. Audrieth, L. F. Yntema, J. Amer. Chem. Soc., 52, 2693(1930).

6) L. F. Audrieth, H. W. Nelson, Chem. Rev., 8, 335(1931).

7) 浜島一郎, 西山東洋婎, 小鳥林平，䉓化，38，184(1970). 
びそのニッケルイオンと錯イオンを形成しやすく電解されにくい

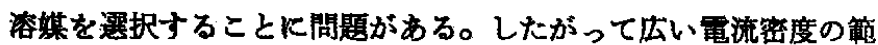
囲で電流效率よく平滑な電着面を得ることがむずかしい。そのう え，浴の性質について十分検討した研究は少ない。

著者らはトリフルオロ酶酸の金属塩を用いた非水溶蚞中での電 析について一連の研究を行なって括りすすでにリフルオロ酢酸

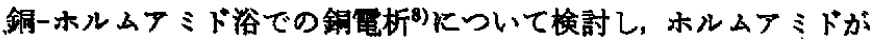
トソフルオロ酷酸銅をよく溶解し、銅イオンと錯イオンを形成し, この浴から得られた電着面は平滑で電流效率すよいことか゚わかっ た。

本研究ではトリフルオャ酢酸ニッケルーホルムアミド浴の性質 を調へ，その浴中でニッケル電析を行ない，電解条件が䉓流效率，

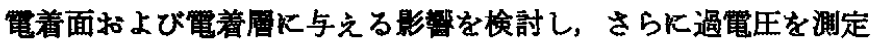
してニッルル電析反宿の解析を行なった。

そして、トリフルオ口拃酸の金属塩を溶解したホルムアミド浴 からの既報の銅奄析》) と本実験のニッヶル䉓析を比較して二三の 考案を行なった。

\section{2 実䮎}

\section{1 試 薬}

ホルムアミド：導電率および粘度の測定には市販の試薬特級 （含水量約 $0.02 \%$ ）を，電析沾よび過電厈測定には試薬一級（含 氷鼻約 $0.12 \%$ ) を使用した。

氷酸化ニッケル：硝酸ニッケル水溶液に過剩のアンモニア皮を 加えてニッケルアンモニア錯イオンを生成させ，つぎに水酸化ナ トリウム水溶液を加えて我酸化ニッケルの沈段を生成させた。こ の沈股物は温水でくり返し洗浄したのら口過してから使用した。

トリフルオロ酢酸ニッケル(以後ニッケル塩と略記する)：水酸 化ニッケルとトリフルオロ酢酸とから中和法により合成した。こ の合成塩の純度は合成塩中に含まれるニッケル量をジメチルグリ オキシムを用いて重量法により定量することにより決めたところ， $99.8 \%$ 以上であった。

その他：リン酸と酢酸は市販の試薬一級を，硫酸，硝酸，塩酸 はそれぞれ試薬特級を使用した。

\section{2 学電事測定}

ニッケル塩ーホルムアミド浴の導電率は, この浴を 30,40 , $50^{\circ} \mathrm{C}$ の亘温办槽中に約 1 時間放置後, 柳本製作所製電気伝導度 湘定装膡 MY-7 型で湘定した。

\section{3 粘 度測定}

ニッケル塩ーホルムアミド浴の粘度は Ostwald 粘度計を用い, 30. $0 \pm 0.1^{\circ} \mathrm{C}$ で測定した。

\section{4 客度測定}

ニッケル塩ーホルムアミド浴およびホルムアミドの密度は，ス プッンゲル比重計を用い, $30.0 \pm 0.1^{\circ} \mathrm{C}$ で測定した。

ニッケル塩ーホルムアミド浴を高温にたるち長時間放置すると 浴中に沈殿物を生成しやすいので，償電率，粘度および密度の湖 定は比較的低い温度で行なった。

\section{5 ガスおよび浴の分析}

ニッケル塩ーホルムアミド浴でニッケル電析を行ならと,カソ 一ドとアノードからわずかにガスの発生がみられた。そこで，こ のガスおよび浴をガスクロマトグラフィーにより分析した。

8）武井たつ子，小島林平：I化，74，2430(1971).
電解にさいしアノードおよびカソードにニッケル板を用いた以 外はすべて既啹の)と同じ測定方法でガス技よび浴の分析を行なっ た。

\section{6 电 析}

常法9にしたがい前処理した銅板とニッケル板をそれぞれカン ードとアノードとし，既報引と同じ電析㱔置を用いて行なった。

電解槽に約 30 分間窒素湓換したホルムアミド $50 \mathrm{ml}$ とニッ ケル塩の所定量を入れて溶解し電析浴とした。ニッケル塩濃度は $20 \sim 200 \mathrm{~g} / l$, 浴温は $40 \sim 70^{\circ} \mathrm{C}$ 飞変化し，浴を一定速度でかきま ぜながら電流密度 $0.5 \sim 10.0 \mathrm{~A} / \mathrm{dm}^{2}$ の範柬内でニッルル䉓析を 行なった。

電析の厚さは通電電気量から算出して 約 $5 \mu$ になるよらにし た。

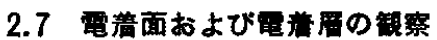

電着面および電着㿉の観察には金虽影徽鏡を使用した。たたし， 電着層の観察は, ニッケル塩浱度 $100 \mathrm{~g} / l$ 浴で電流密度 $1.0 \mathrm{~A} / \mathrm{dm}^{2}$ Kして浴温を $40,50,60^{\circ} \mathrm{C}$ に变化して電析を行ない, それぞれ 電析の厚さが通電電気量から算出して約 $25 \mu$ のものを試料とし，

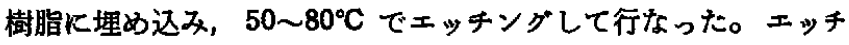
ング液は容量でリン酸：酢酸：水：硝酸：硫酸=25:15:5: $1: 2$ の混合溶液である。

\section{$2.8 \mathrm{X}$ 緗回折测定}

ニッケル塩濃度 $100 \mathrm{~g} / l$ (浴温 $60^{\circ} \mathrm{C}$ ) で電流密度 $1.0 \mathrm{~A} / \mathrm{dm}^{2}$ と $3.0 \mathrm{~A} / \mathrm{dm}^{2}$ の場合に，通電電気暑から算出して約 $25 \mu$ の厚さに ニッケルを電析したるのを試料とし，理学電機株式会社製デフラ クトメーターD-8C（ターゲットに銅, フィルターKニッケル） を用いてX緗回折を行なった。

\section{9 過曋王測定}

ニッケル塩ーホルムアミド浴からのニッケル電析に扣りる過電 王の湘定装置および測定方法は既報8) と同じである。

たたしニッケル析出過電圧は，銅板にあらかじめ電流密度 $1.0 \mathrm{~A} / \mathrm{dm}^{2}$ で通電電気量から䇺出して約 $5 \mu$ の厚さにニッケル を電析したるのをカソードとし、ニッケル板をアノードとして， ニッケル塩濃度 $50 \mathrm{~g} / l\left(17.5 \times 10^{-5} \mathrm{~mol} / \mathrm{ml}\right), 100 \mathrm{~g} / l\left(35.0 \times 10^{-5}\right.$ $\mathrm{mol} / \mathrm{ml})$ および $150 \mathrm{~g} / l\left(52.5 \times 10^{-6} \mathrm{~mol} / \mathrm{ml}\right)$ の浴について，そ れぞれ浴温を $50 ， 60,70^{\circ} \mathrm{C}$ に変化して測定した。

\section{3 実験結果および考察}

\section{1 ニッケル算一ホルムアミト溶液の性質}

3.1.1 ニッケル塩の溶媒化分解 : 硫酸銅-ホルムアミド溶夜 ${ }^{10}$

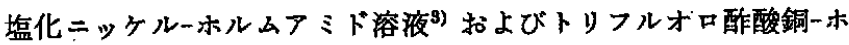
ルムアミド溶液帛)の中ではそれぞれ溶媒化分解が起こるので，二

9）吉沢四郎，“電気化学実験法”，いす好書票 (1964) p. 389.

10）有機合成化学協会編, “有機溶剤ボケットブック”，オーム 社 (1967) p.701.

11）小寺 明, “物理化学实験法”, 朝會書店 (1958) p. 91.

12) F. Denise, H. Leidheiser, J. Electrochem. Soc., 100 , 490(1953).

13）笠井暢民，角户正夫，渡瀬武男，電化，21，215(1945).

14) I. A. Menzies, T. Broughton, V. O. Nwoko, Trans. Inst. Metal Finish., 43, 9(1965).

15) A. Brenner, "Advances in Electrochemistry and Electrochemical Engineering", ed. by P. Delahay, C. W. Tobias, Intersience Pub. (1967) Vol. 5, p. 206. 
ッケル塩ーホルムアミド溶液中でる（1）式で示された溶媒化分解 が起こることが予想される。

$$
\begin{aligned}
& \mathrm{Ni}\left(\mathrm{CF}_{3} \mathrm{COO}\right)_{2}+4 \mathrm{HCONH}_{2} \\
& \quad \longrightarrow \mathrm{Ni}(\mathrm{HCONH})_{2} \cdot 2 \mathrm{HCONH}_{2}+2 \mathrm{CF}_{3} \mathrm{COOH}
\end{aligned}
$$

実際に, ニッケル塩ーホルムアミド溶庥ではニッヶル塩の濃度 の低い $20 \sim 100 \mathrm{~g} / \mathrm{l}$ 浴を 70 90 $\mathrm{C}$ で数時間加温するか，あるい はニッケル塩の濃度の高い浴を室温で約 1 週間放置するとニッケ ル塩とホルムアミドが反応して淡黄緑色の沈殿物を生成する。

このロ夜はほとんと無色透明で，これをガスクロマトグラフィ 一で分析したところトリフルオロ酶酸が検出された。

また沈段物をnーへキサンとアセトンで洗浄し，乾嬠後，その一 定量炕含まれるニッケル量をジメチルグリオキシム（重量法）を 用いて定量したところ，その值は沈股物の分子式を $\mathrm{Ni}(\mathrm{HCONH})_{2}$ $.2 \mathrm{HCONH}_{2}$ としたときのニッケルの理論含有量の約 $96.8 \%$ で あった。

以上の結果から、ニッケル盐ーホルムアミド溶液中では（1）式 の反応が起こっている。

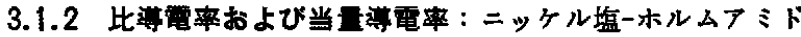
溶淮の比導電率および当量導電率を図 1 亿示した。

いずれの温度の場合もニッケル塩濃度の增加にともない比導電 率は増加し当量導電率は減少するが，ニッケル塩濃度が $100 \mathrm{~g} / \mathrm{l}$ 程度以上になるとニッケル塩濃度の堌加に対する比導電率の堌加 の割合および当量導電率の減少の割合が小さくなり、ニッケル塩 漉度が $200 \mathrm{~g} / l$ 以上では比導電率および当量導電率はほとんどー 定値に近づいた。

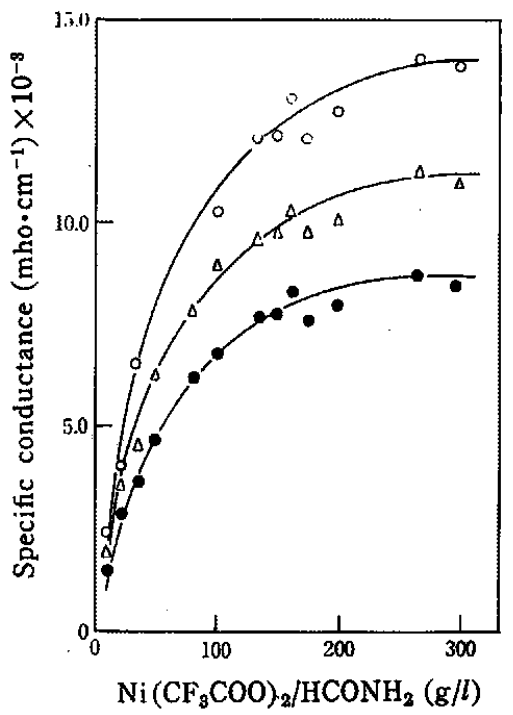

Fig. 1-1 Specific conductance of $\mathrm{Ni}\left(\mathrm{CF}_{3} \mathrm{COO}\right)_{2}-\mathrm{HCONH}_{2}$ solutions

$$
\mathrm{O}: 50^{\circ} \mathrm{C}, \triangle: 40^{\circ} \mathrm{C}, \quad: 30^{\circ} \mathrm{C}
$$

16) D. E. Couch, A. Brenner, J. Electrochem. Soc., 99, 234 (1952).

17) A. Brenner, ibid., 103, 652(1956).

18) H. Connor, A. Brenner, ibid., 103, 657 (1956).

19) I. A. Menzies, Trans. Inst. Metal Finish., 39, 172(1962).

20) I. A. Menzies, B. S. White, ibid., 46, 65(1968).

21）林 忠夫, 石田武男, 電化，30，552(1962).

22）林忠夫, 溶融塩, $7,507(1964)$.

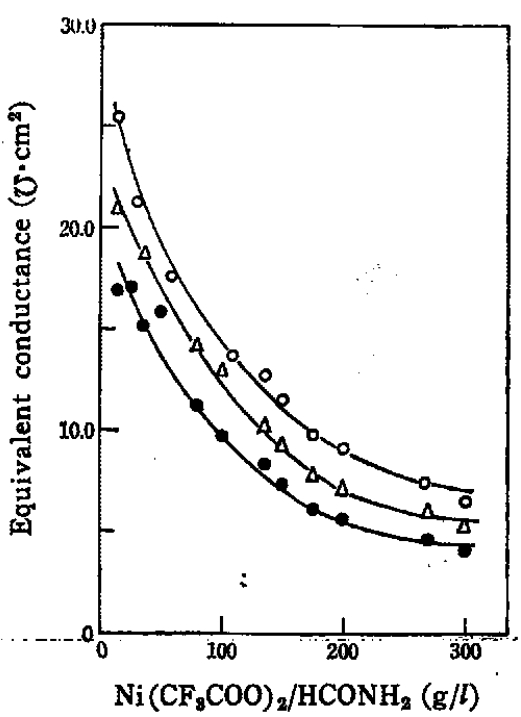

Fig, 1-2 Equivalent conductance of $\mathrm{Ni}\left(\mathrm{CF}_{3} \mathrm{COO}\right)_{2}$ $\mathrm{HCONH}{ }_{2}$ solutions

$\mathrm{O}: 50^{\circ} \mathrm{C}, \triangle: 40^{\circ} \mathrm{C}, \quad \bigcirc: 30^{\circ} \mathrm{C}$

ニッケル塩瀑度が $200 \mathrm{~g} / l$ 以上の溶液中ではニッケル塩がもは や解離せず，むしろ非解離のニッケル塩のためにイオンの移動が 妨げられているあのと考えられる。

3.1.3で述べるよ5に, ニッケル塩溚度の増加にとすない溶液 の粘度が增大することもニッケル塩濃度の高い溶液の導電性る悪 くしている一因と考光られる。

ニッケル塩ー亦ルムアミド溶液の比導電率および当量導䉓率は 同し温度で，しかもニッケル塩濃度の等しいニッケル塩一塩化ア ルミニウムーメタノール溶液》，あるいはニッケル塩浐度と等しい

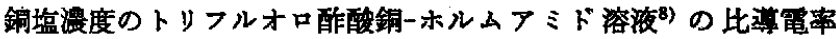
および当量導電率と洼とんと同じであった。

3.1.3 粘度: ニッケル㙁-ホルムアミド溶波の粘度を図 2 《示 した。

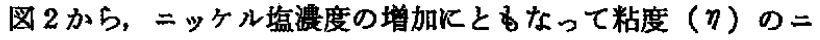
ッケル塩濃度に対する增加の割合が大きくなることがわかった。

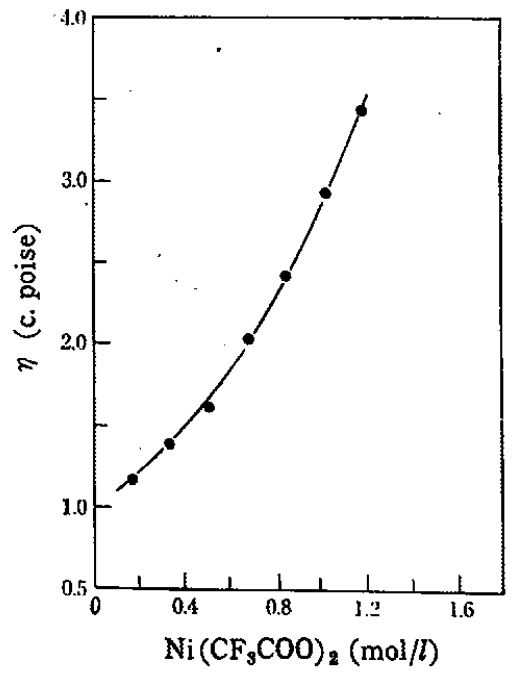

Fig. 2 Relationship between viscosity $(\eta)$ and concentration of $\mathrm{Ni}\left(\mathrm{CF}_{3} \mathrm{COO}\right)_{2}$ in $\mathrm{Ni}\left(\mathrm{CF}_{3} \mathrm{COO}\right)_{2}-\mathrm{HCONH}_{2}$ solutions at $30^{\circ} \mathrm{C}$ 
3.1 .4 見かけの分子容：見かけの分子容 $(\phi)$ は， $30.0 \pm 0.1^{\circ} \mathrm{C}$ で测定した浴の密度を次式 (2) ${ }^{11}$ 火代入して求めた。

$$
\phi=1 / m\left[\left(1000+m M_{2}\right) / d-1000 / d_{1}\right]
$$

$$
m: \text { 溶繁の重量モル浱度 }
$$

$M_{2}:$ 溶賀の分子曹

\section{$d$ : : 溶液の整度}

\section{$d_{1}:$ 溶媒の密度}

\section{その結果を図 3 K示した。}

ニッケル㙁ーホルムアミド溶液中では，ニッケル塩濃度の増加 にとるない見かけの分子容は增加した。そして，ニッケル塩濃度 がおよそ $0.90 \mathrm{~mol} / l(256 \mathrm{~g} / l)$ 以上飞なると，見がけの分子容は 注活一定値 $140 \mathrm{~cm}^{3} / \mathrm{mol}$ Kなった。

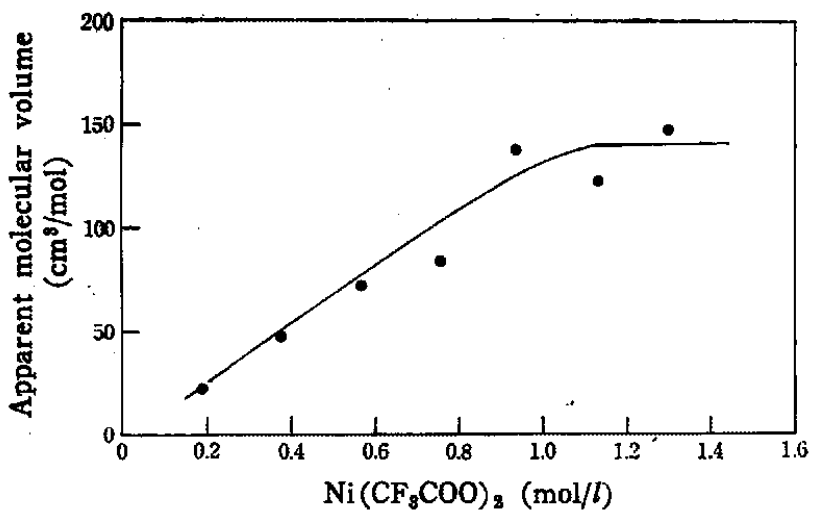

Fig. 3 Relationship between apparent molecular volume and concentration of $\mathrm{Ni}\left(\mathrm{CF}_{3} \mathrm{COO}\right)_{2}$ in $\mathrm{Ni}\left(\mathrm{CF}_{8} \mathrm{COO}\right)_{2-}$ $\mathrm{HCONH}_{2}$-solutions at $30^{\circ} \mathrm{C}$

ニッケル塩ーホルムアミド溶夜中では見かけの分子容がプラス 值を現わしているので, ニッケルイオンを $\mathrm{HCONH}^{-} や \mathrm{CF}_{9} \mathrm{COO}^{-}$ がとり囲んでいて，これが周囲のホルムアミドを排除しているよ らな状態を想像することができる。また，ニッケル塩濃度の增加 で 3.1.1で述へたよらK Ni(HCONH $)_{2} \cdot 2 \mathrm{HCONH}_{2}$ が生成しや すくなり，一方，非解離の二ッタル塩す増加するので，ニッケル 㙁濃度が $0.9 \mathrm{~mol} / l$ 以上飞なると溶液中のニッケルイオンは汪々 んぞ $\mathrm{Ni}(\mathrm{HCONH})_{2} \cdot 2 \mathrm{HCONH}_{2}$ あるいは非解離のニッケル塩の状 態で存在するよ5となるるのと想像することができる。

以上の結果から、ニッケル塩-ホルムアミド溶液はニッケル塩 瀑度の増加で粘度が増大し, 非解離のニッケル塩す增加するため 递電性が向上せず，その上， $\mathrm{Ni}(\mathrm{HCONH})_{2} \cdot 2 \mathrm{HCONH}_{2}$ の沈殿を 生成しやすいので, ニッケル電析浴としてはニッケル塩蕞度を $200 \mathrm{~g} / \mathrm{l}$ 以下にするのがよいと教えられる。

\section{2 電 析}

ニッケル䉓析のさいに，ニッケル塩湦度がアノードおよびカソ 一ドの電流効深に与える影響を浴温 $50^{\circ} \mathrm{C}$ の場合を例として図 4 に示した。

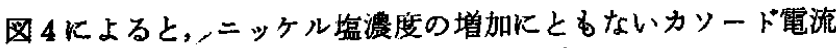
奻率は上昇し，一方，アノ一ト電流効率は逆任低下する傾向を示 した。そして，カッード電流北率が約 90\% Kなったのはニッろ ル塩浱度が $100 \mathrm{~g} / \mathrm{l}$ 浴では電流密度 $2.0 \mathrm{~A} / \mathrm{dm}^{2}$ のときだけで ったが、 ニッケル塩渡度が $80 \mathrm{~g} / l$ 浴では $3.0 \sim 5.0 \mathrm{~A} / \mathrm{dm}^{2}$ の電

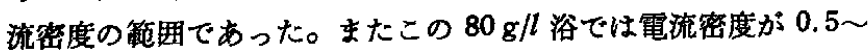

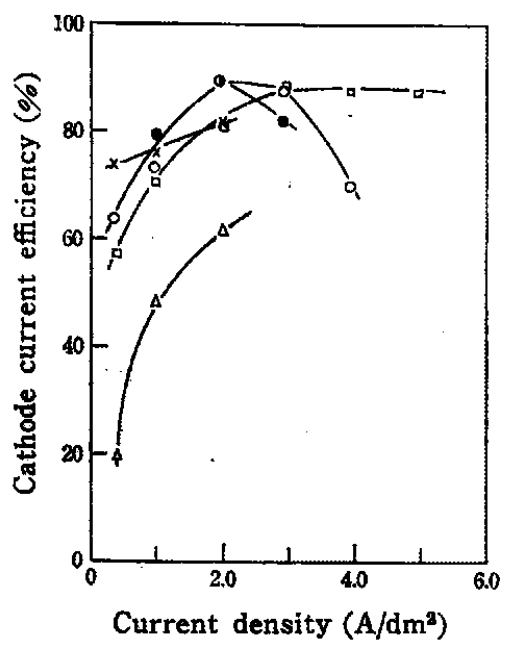

Fig: 4-1 Cathode current efficiency as a function of current density for $\mathrm{Ni}\left(\mathrm{CF}_{8} \mathrm{COO}\right)_{2}-\mathrm{HCONH}_{2}$ baths at $50^{\circ} \mathrm{C}$

$$
\begin{aligned}
& \mathrm{Ni}\left(\mathrm{CF}_{3} \mathrm{COO}\right)_{2}-(\mathrm{g}) / \mathrm{HCONH}_{2} 1 \mathrm{l} \\
& \triangle: 20, \square: 80, \mathrm{O}: 100, \times: 150, \bigcirc: 200
\end{aligned}
$$

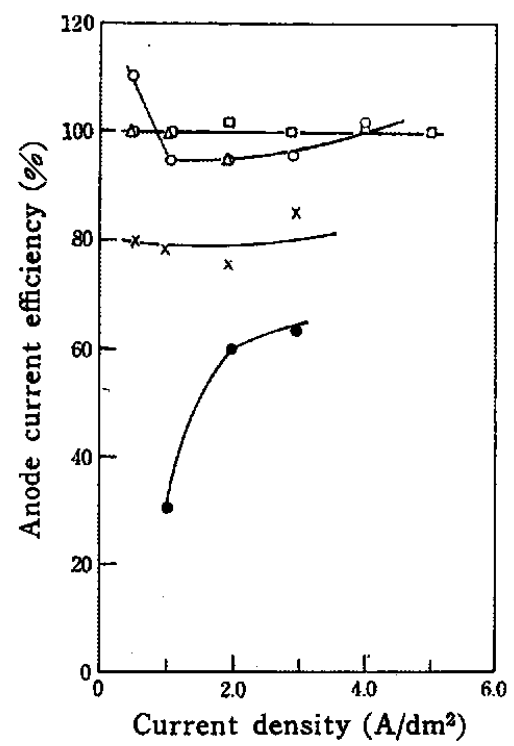

Fig. 4-2 Anode current efficiency as a function of current density for $\mathrm{Ni}\left(\mathrm{CF}_{3} \mathrm{COO}\right)_{2}-\mathrm{HCONH}_{2}$ baths at $50^{\circ} \mathrm{C}$

$\mathrm{Ni}\left(\mathrm{CF}_{3} \mathrm{COO}\right)_{2}-(\mathrm{g}) / \mathrm{HCONH}_{2} 1 l$

$\triangle: 20, \square: 80, \bigcirc: 100, X: 150, \bigcirc: 200$

$5.0 \mathrm{~A} / \mathrm{dm}^{2}$ の範囲内でアノード電流效率を約 $100 \%$ 、維持し得 た。

つぎに, ニッケル電析のさい浴温がアノードおよびカソード の電流效率炕与学る影響をニッケル塩濃度 $100 \mathrm{~g} / l$ 浴を例として 图 5 亿示した。アノード電流效率はいずれの浴温です100\%に 近い値となった。一方, カソード電流效率は, $50^{\circ} \mathrm{C}$ と $70^{\circ} \mathrm{C} の$ 浴温では 4.0 5.0 A/dm² の高電流密度で減少し, 浴温 $60^{\circ} \mathrm{C}$ の ときのみ $2.0 \mathrm{~A} / \mathrm{dm}^{2}$ 以上 $7.0 \mathrm{~A} / \mathrm{dm}^{2}$ と高い電流密度になっても 約 $90 \%$ の值を維持し得た。

これらの結果からニッケル塩ホホルムアミド浴ではニッケル塩 浱度が $80 \sim 100 \mathrm{~g} / \mathrm{l}$ で, 浴温 $60^{\circ} \mathrm{C}$ のときにカソードおよびァ। 一ドの笔流効率が一番よいことがわかる。 


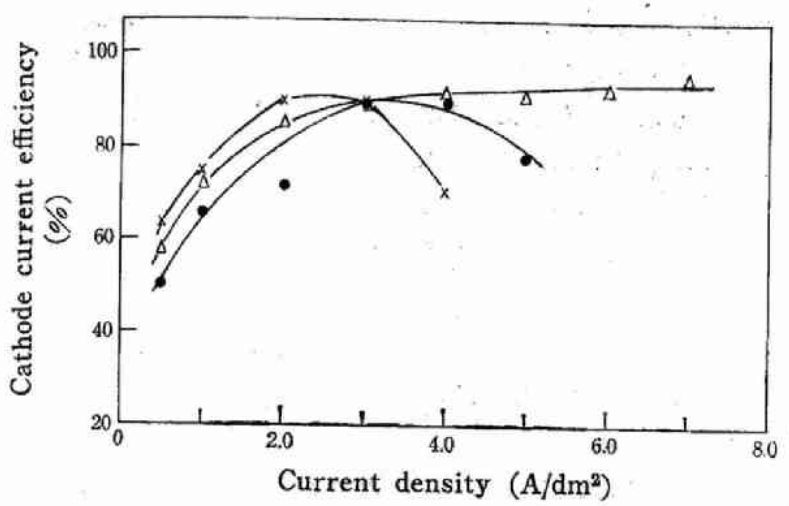

Fig. 5-1 Cathode current efficiency as a function of current density for $\mathrm{Ni}\left(\mathrm{CF}_{3} \mathrm{COO}\right)_{2} 100 \mathrm{~g} / \mathrm{HCO}$. $\mathrm{NH}_{2} 1 l$ bath at various temperatures $\times: 50^{\circ} \mathrm{C}, \triangle: 60^{\circ} \mathrm{C}$,

: $70^{\circ} \mathrm{C}$

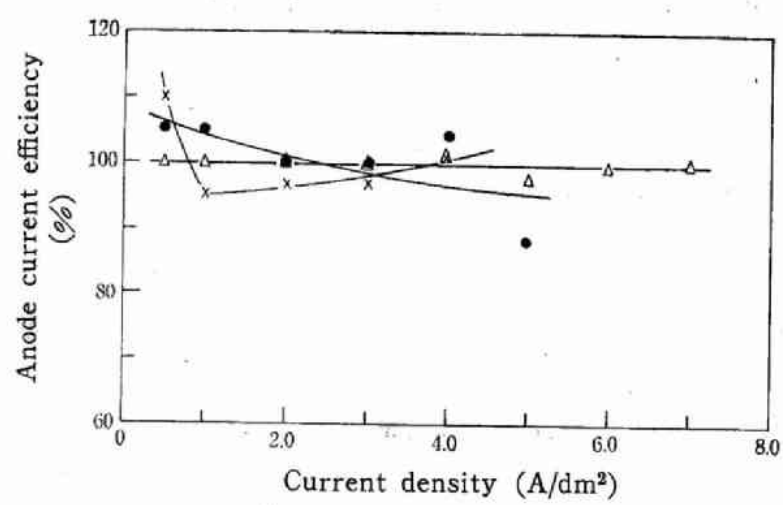

Fig. 5-2 Anode current efficiency as a function of current density for $\mathrm{Ni}\left(\mathrm{CF}_{3} \mathrm{COO}\right)_{2} 100 \mathrm{~g} / \mathrm{HCO}$. $\mathrm{NH}_{2} 1 l$ bath at various temperatures

: $70^{\circ} \mathrm{C}, \triangle: 60^{\circ} \mathrm{C}, \times: 50^{\circ} \mathrm{C}$

なお，電解中にカソードからわずか炕発生したガスは水素であ った。したがってカソード電流効率低下の原因はこの水素ガス発 生のためである。この水素は（1）式の反応の結果生成したトリ フルオロ酰酸の解離によって生じた $\mathrm{H}^{+}$の放電によるるのと考え られる。お, アノードからもガスの発生がみられたが, その発 生量はカソードからのガス発生量にくらへてでくわずかであっ た。アノードから発生したガスは二酸化炭素であった。アノード でも浴の電解がわずか炕起こっていることを示している。

ニッケル塩ーホルムアミド浴から，光沢があってしかも素地と の密着性もよい電析物が得られる電流密度の䇺囲を表 1 に示し た。この電流密度より高い電流密度でも光沢のよい電析物が得ら れたが，素地との密着性がよくなかった。

Table 1 The range of current density for bright and adherent nickel deposit in $\mathrm{Ni}\left(\mathrm{CF}_{3} \mathrm{COO}\right)_{2}-\mathrm{HCO}$. $\mathrm{NH}_{2}$ bath

\begin{tabular}{ccccc}
$\begin{array}{c}\text { Bath } \\
\text { temp. } \\
\left({ }^{\circ} \mathrm{C}\right)\end{array}$ & \multicolumn{4}{c}{$\mathrm{Ni}\left(\mathrm{CF}_{3} \mathrm{COO}\right)_{2}(\mathrm{~g} / \mathrm{l})$} \\
\cline { 2 - 5 } & 80 & 100 & 150 & 200 \\
\hline 40 & $1.0 \sim 2.0$ & & $0.5 \sim 1.0$ & \\
50 & $1.0 \sim 2.0$ & $1.0 \sim 2.0$ & $0.5 \sim 2.0$ & $1.0 \sim 2.0$ \\
60 & & $0.5 \sim 2.0$ & & \\
70 & & $0.5 \sim 4.0$ &
\end{tabular}

また, ニッケル塩 $20 \mathrm{~g} / l$ 浴からの電析物の光沢はよいが素地 から㔀離しやすかった。

結局, ニッケル塩濃度 $80 \sim 200 \mathrm{~g} / \mathrm{l}$ 浴から，電流密度 $0.5 \sim 2.0$ $\mathrm{A} / \mathrm{dm}^{2}$ の範囲内で，光沢があって素地と密着した電析物が得ら れた。この範囲はニッケル塩-塩化アルミニウムーアルコール浴 ${ }^{7}$ からの場合にくらべて狭い。

なお, 高温の浴から得られた電析物は素地との密着性がかっ た。

以上の結果からニッケル塩-ホルムアミド浴中で, 光沢のある 素地との密着性のよい電析物が効率よく得られる条件はニッケル 塩濃度が $80 \sim 100 \mathrm{~g} / l$ 浴で浴温 $60^{\circ} \mathrm{C}$, 電流密度 $0.5 \sim 2.0 \mathrm{~A} / \mathrm{dm}^{2}$ の場合であることが明らかになった。

そして, ニッケル塩ーホルムアミド浴に適当な添加剤を添加す ることにより，電析物の素地との密着性が改善されれば良好な電 析物の得られる電流密度の範囲を広げることができることが予想 される。

\section{3 電着面およひ電着層}

ニッケル塩ーホルムアミド浴から得られたニッケル電析物の電 着面および電着層の一例を写真 1 に示した。

低電流密度で得られた良好な電着面は平滑で，非常にこまかい 粒状で, 電流密度が大きくなると丸味のあるプロックやキレッを 生じた。浴温が低いと低電流密度でもキレッやブロックを生じや すい。そして浴温 $60^{\circ} \mathrm{C}$ のとき，低電流密度で非常にこまかい粒 状の平滑な電着面が得られやすいことがわかった。

浴温 $50^{\circ} \mathrm{C}$ と $60^{\circ} \mathrm{C}$ のときの電着層は粒状組織であった。浴温 $40^{\circ} \mathrm{C}$ では電析物が素地から䐣離してしまった。

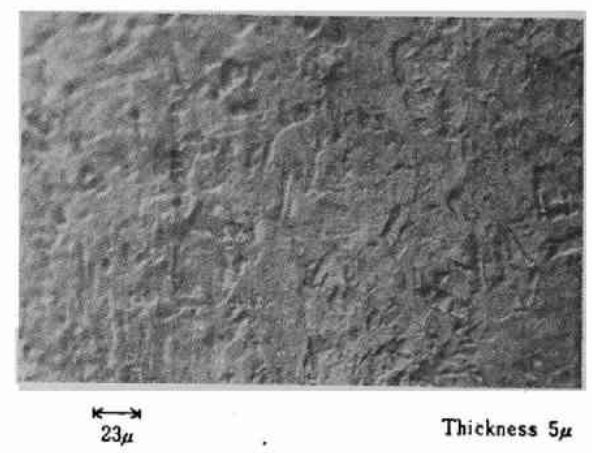

Photo 1-1 Surface of nickel deposit obtained from $\mathrm{Ni}$. $\left(\mathrm{CF}_{3} \mathrm{COO}\right)_{2} 100 \mathrm{~g} / \mathrm{HCONH}_{2} 1 l$ bath at $1.0 \mathrm{~A} / \mathrm{dm}^{2}$ at $60^{\circ} \mathrm{C}$

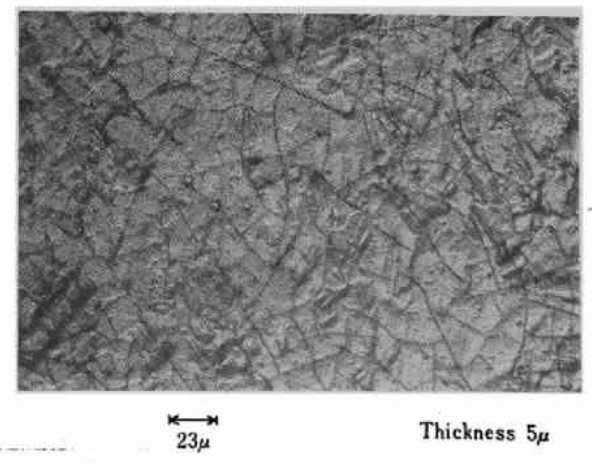

Photo 1-2 Surface of nickel deposit obtained from $\mathrm{Ni}$. $\left(\mathrm{CF}_{3} \mathrm{COO}\right)_{2} 150 \mathrm{~g} / \mathrm{HCONH}_{2} 1 l$ bath at $0.5 \mathrm{~A} / \mathrm{dm}^{2}$ at $40^{\circ} \mathrm{C}$ 


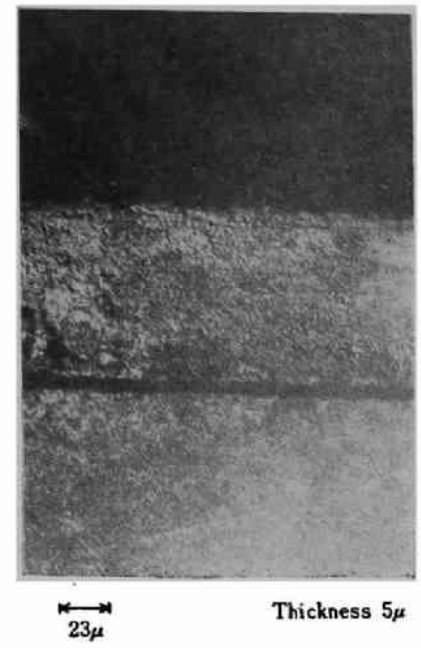

Photo 1-3 Cross-section of nickel deposit obtained from $\mathrm{Ni}\left(\mathrm{CF}_{3} \mathrm{COO}\right)_{2} 100 \mathrm{~g} / \mathrm{HCONH}_{2} 1 l$ bath at $1.0 \mathrm{~A} /$ $\mathrm{dm}^{2}$ at $50^{\circ} \mathrm{C}$

ニッケル塩-ホルムアミド浴中ではニッケルイオンが錯イオン を形成しており，電析のさいに配位子が電極上へ弱く吸着し adatom の表面拡散を抑制するので, 垂直方向の生長が阻止されて, 核発生のヒン度が高くなり緻密な細かい結晶となり，粒状組織を 形成するものと考学られる。

\section{4 結晶構造}

ニッケル塩ーホルムアミド浴から得られた電析物の $\mathrm{X}$ 線回折図 形は図 9 に示した。

3.4.1 結晶格子：通常のニッケルは面心立方格子なので, = ッケル塩ーホルムアミド浴から得られた電析ニッケルも面心立方 格子とし, その格子定数 $\left(a_{0}\right)$ を求め表 2 に示した。

ニッケル塩ーホルムアミド浴から得られた電析ニッケルは格子 定数 $3.50 \sim 3.52 \AA$ で, この値は既知值 ${ }^{12)}$ と一致している。

3.4.2 結晶（粒）子の大きさ：結晶子の大きさ（結晶子の值径 $\left.D_{h k l}\right)$ は（3）式から求め表 2 に示した。

$$
D_{h k l}=0.9 \lambda / \beta_{1 / 2} \cdot \cos \theta
$$

$\lambda: \mathrm{Cu} K_{\alpha}=1.54(\AA)$

$\beta_{1 / 2}$ : 半価幅 (Rad)

$2 \theta$ : 回折角

ニッケル塩ーホルムアミド浴から得られた電析ニッケルの結晶 子の大きさは (111) 面, (200) 面, (220) 面とも大差がなく 70

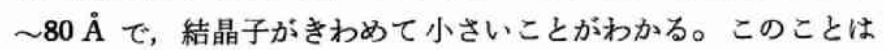
電析中に核発生ヒン度が大きいことを意味するすのである。

3.4.3 結晶子の配向性 : ニッケル塩-ホルムアミド浴から得ら れた電析ニッケルの結晶子は強い[111] 配向と弱い [220] およひ [200］配向をしていた。

このように各結晶子がある特定の面すなわち (111) 面がいちじ るしく発達し，しかもこれらが電着面に平行に配列されているこ

Table 2 The results of $\mathrm{X}$-ray analysis for nickel deposit from $\mathrm{Ni}\left(\mathrm{CF}_{3} \mathrm{COO}\right)_{2}-\mathrm{HCONH}_{2}$ bath

\begin{tabular}{cccccc}
$(h k l)$ & $\beta_{1 / 2}$ & $2 \theta$ & $d$ & $a_{0}$ & $D_{h k l}$ \\
\hline$(111)$ & 1.10 & 44.5 & 2.03 & 3.51 & 77.8 \\
$(200)$ & 1.20 & 52.0 & 1.75 & 3.50 & 74.1 \\
$(220)$ & 1.30 & 76.4 & 1.25 & 3.52 & 77.8
\end{tabular}

と,および，各結晶子がきわめて小さいことか゚ニッケル塩ーホル ムアミド浴からの電析物の光沢をよくしているるのと考えられ る。このよらな結果をるたらしたのは3.3で述べたよらに，浴中 のニッケル錯イオンによるるのである。

なお，ワッッ浴からの電析物の結晶子は電流密度 $1.0 \mathrm{~A} / \mathrm{dm}^{2}$ 以上の場合に [100] 配向をしており ${ }^{12)}$, 普通浴からの電析物の結 晶子は電流密度 $1.0 \mathrm{~A} / \mathrm{dm}^{2}$ の場合に [111] 配向をしている ${ }^{18)}$ 。

ニッケル塩ーホルムアミド浴からの電析物の結晶子の配向性と 普通浴からのそれとが一致していることがわかった。

\section{5 活性化過電圧}

すでに既報 ${ }^{8)}$ で报ったように，電解電流遮断後 4 ミリ秒間の過 電圧の Decay 曲線から抵抗分極を差し引いた過電圧を活性化過 電圧とした。

3.5.1 ニッケル電析反応における 活性化過電圧と電流密度の 関係: ニッケル析出の 活性化過電圧 $\left(\eta_{\mathrm{c}}\right)$ と電流密度 $\left(i_{\mathrm{c}}\right)$ との 関係についてニッケル塩濃度 $100 \mathrm{~g} / \mathrm{l}$ 浴を例として図 6 K示し た。電流密度 $1.0 \sim 4.0 \mathrm{~A} / \mathrm{dm}^{2}$ の範囲内で $\eta_{\mathrm{c}}$ と $\log i_{\mathrm{c}}$ との間に は Tafel の関係が成立している。この電流密度の範囲はニッケ ル塩濃度の変化で多少変わった。

結局, ニッッル塩ーホルムアミド浴で $\eta_{\mathrm{c}}$ と $\log i_{\mathrm{e}}$ が Tafel の 関係を示す電流密度の範囲は浴温 $50^{\circ} \mathrm{C}$ で $0.9 \sim 2.3 \mathrm{~A} / \mathrm{dm}^{2}, 60$ ${ }^{\circ} \mathrm{C}$ で $0.9 \sim 4.4 \mathrm{~A} / \mathrm{dm}^{2}, 70^{\circ} \mathrm{C}$ で $0.9 \sim 4.8 \mathrm{~A} / \mathrm{dm}^{2}$ であった。こ の $\eta_{\mathrm{c}}$ と $\log i_{\mathrm{c}}$ が Tafel の関係を示す電流密度の範囲内では電 荷移動過程が律速になっているものと考えられる。

3.5.2 ニッケル析出の交換電流密度 $\left(\boldsymbol{i}_{0 \mathrm{c}}\right)$ : 図6 に拧いて $\eta_{\mathrm{c}}$ を 0 に外插して得られるニッケル析出の交換電流密度 $\left(i_{0 \mathrm{c}}\right)$ を各 ニッケル塩濃度および浴温について求め, 表 3 に示した。

$i_{0 \mathrm{c}}$ の值はニッケル塩濃度拉よび浴温の上昇にともない增加す る傾向を示し, ニッケル塩-塩化アルミニウムーアルコール浴から の値で近かった。

また, ホルムアミド浴では, ニッケル析出の交換電流密度は銷

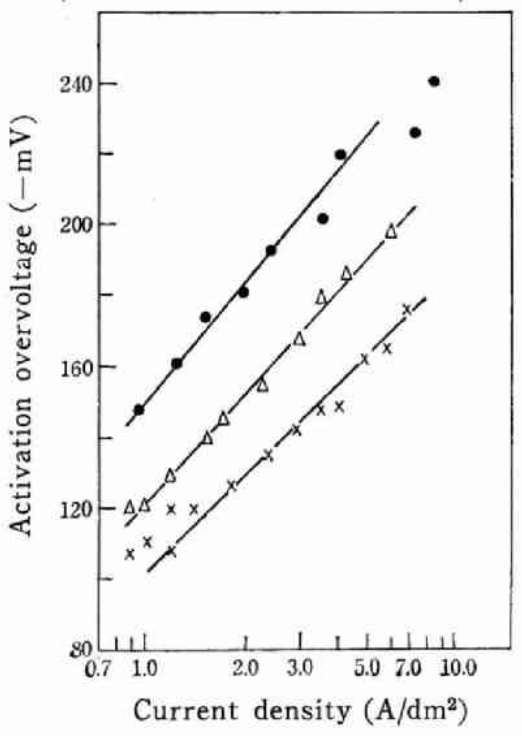

Fig. 6 Relationship between activation overvoltage and current density in the electrodeposition of nickel from $\mathrm{Ni}\left(\mathrm{CF}_{3} \mathrm{COO}\right)_{2}-\mathrm{HCONH}_{2}(100 \mathrm{~g} / \mathrm{l})$ bath at various temperatures

: $50^{\circ} \mathrm{C}, \triangle: 60^{\circ} \mathrm{C}, \times: 70^{\circ} \mathrm{C}$ 
Table 3

\begin{tabular}{|c|c|c|c|c|c|c|}
\hline $\begin{array}{c}\mathrm{Ni}\left(\mathrm{CF}_{\mathrm{g}^{\circ}}\right. \\
\mathrm{COO})_{2} \\
(\mathrm{~mol} / \mathrm{ml})^{-5} \\
\times 10^{-5}\end{array}$ & $\begin{array}{c}\text { Bath } \\
\text { temp. } \\
\left({ }^{\circ} \mathrm{C}\right)\end{array}$ & $\frac{i_{0 \mathrm{c}}}{\left(\mathrm{d} / \mathrm{m}^{2}\right)}$ & $\alpha_{\mathrm{c}}$ & $\alpha_{\mathrm{c}} n$ & $n$ & $\begin{array}{c}b_{\mathrm{c}} \\
(-\mathrm{V})\end{array}$ \\
\hline \multirow{3}{*}{$\cdot 17.5$} & 50 & 0.030 & 0.520 & 0.644 & 1.23 & 0.100 \\
\hline & 60 & 0.055 & 0.694 & 0.604 & 0.870 & 0.110 \\
\hline & 70 & 0.070 & 0.764 & 0.684 & 0.895 & 0.100 \\
\hline \multirow{3}{*}{35.0} & 50 & 0.040 & 0.520 & 0.602 & 1.15 & 0.107 \\
\hline & 60 & 0.065 & 0.694 & 0.651 & 0.938 & 0.102 \\
\hline & 70 & 0.080 & 0.764 & 0.735 & 0.962 & 0.093 \\
\hline \multirow{3}{*}{52.5} & 50 & 0.050 & 0.520 & .0 .607 & 1.16 & 0.106 \\
\hline & 60 & 0.075 & 0.694 & 0.651 & 0.938 & 0.102 \\
\hline & 70 & 0.090 & 0.764 & 0.684 & 0.895 & 0.100 \\
\hline
\end{tabular}

析出の交換電流密度8) より小さいことがわかった。

3.5 .3 ニッヶル折出の見かけの通過你数 $\left(\boldsymbol{\alpha}_{\mathrm{e}}\right)$ および胃かけの 俩数 $(\boldsymbol{n}):=ッ$ ル析出の交換電流密度 $\left(i_{0 c}\right)$ と 2 洒の=ッケル イオン溚度 $\left(C_{0} \mathrm{~mol} / \mathrm{ml}\right)$ との関係を図 7 に示した。 $\log i_{0 c}-\log$ C、のプロットが直線関係にあるとみなし，その勾配から $\alpha_{\mathrm{c}}$ の 値を求めた。一方, 图6の Tafel 線の勾配が $2.303 \times R T j \alpha_{\mathrm{c}} n \boldsymbol{F}$ に等しいのでこの関係から $\alpha_{\mathrm{c}} n$ の值を求めた。つぎ $\alpha_{\mathrm{c}}$ と $\alpha_{\mathrm{c}} n$ の值からnの值を算出した。

得られた $\alpha_{\mathrm{e}}, \alpha_{\mathrm{c}} n, n$ おび Tafel 線の勾配 $\left(b_{\mathrm{s}}\right)$ の值を表 3 沃示した。

これらの結果を平均すると $\alpha_{\mathrm{c}}=0.66$ (すなわち， d $\log i_{0 \mathrm{c}} / \mathrm{d} \log$ $\left.C_{0}=0.34\right), n=1.00, b_{\mathrm{c}}=-0.102 \mathrm{~V}$ であった。

それゆえ、ニッケル塩ーホルムアミド浴からのニッケル電析反 応は，電流密度がおよそ $0.9 \sim 4.8 \mathrm{~A} / \mathrm{dm}^{2}$ の範囲内では (4), (5) 式のように反応が進行しているすのと考えられる。

$$
\begin{aligned}
& \mathrm{Ni}^{2+}+e^{-} \longrightarrow \mathrm{Ni}^{+} \\
& \mathrm{Ni}^{+}+e^{-} \longrightarrow \mathrm{Ni}^{0}
\end{aligned}
$$

また，良好な電析物の得られる低電流密度に括いては電位（電

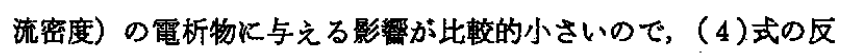
応が律速になっているものと考えられる。

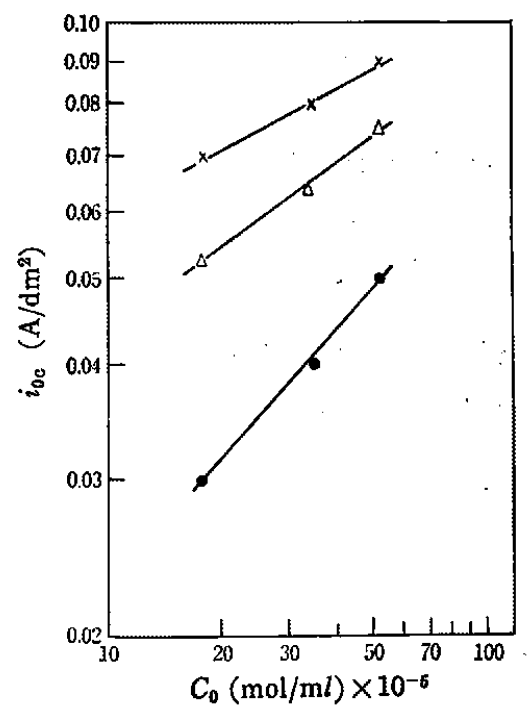

Fig. 7 Relationship between $\log i_{0 \mathrm{c}}$ and $\log C_{0}$ in $\mathrm{Ni}$. $\left(\mathrm{CF}_{3} \mathrm{COO}\right)_{2}-\mathrm{HCONH}_{2}$ bath at various temperatures

: $50^{\circ} \mathrm{C}, \triangle: 60^{\circ} \mathrm{C}, \times: 70^{\circ} \mathrm{C}$

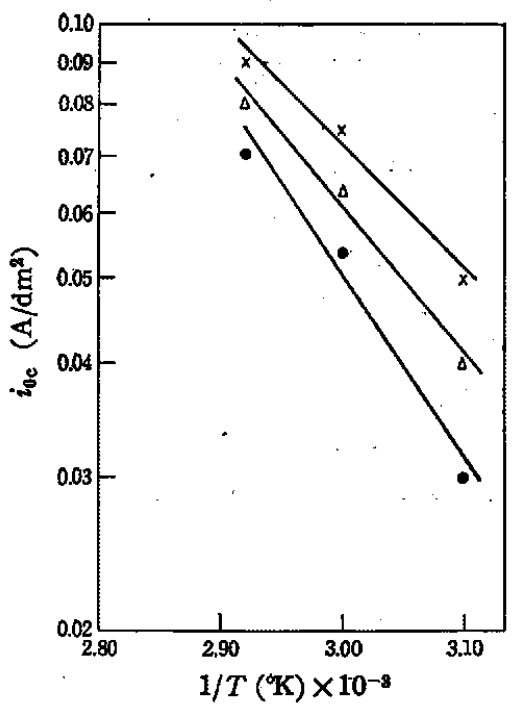

Fig. 8 Relationship between $\log i_{0 \mathrm{e}}$ and $1 / T$ in $\mathrm{Ni}\left(\mathrm{CF}_{9}\right.$. $\mathrm{COO})_{2}-\mathrm{HCONH}_{2}$ bath at various concentrations of $\mathrm{Ni}\left(\mathrm{CF}_{9} \mathrm{COO}\right)_{2}$

$: 17.5 \times 10^{-6} \mathrm{~mol} / \mathrm{ml}, \triangle: 35.0 \times 10^{-5} \mathrm{~mol} / \mathrm{ml}$, $\times: 52.0 \times 10^{-6} \mathrm{~mol} / \mathrm{ml}$

ニッケル塩ーホルムアミド浴からのニッケル析出のさいの $b_{\mathrm{c}}$ 值 はトリフルオロ醀酸鍽ーホルムフミド浴 ${ }^{8)}$ からの銅析出のさいの b。值とほとんど等しい值を示した。

3.5.4 ニッケル析出の見かけの活性化エネルギー：ニックル 析出の交換電流密度 $\left(i_{0 \mathrm{c}}\right)$ と浴温 $(T)$ との関俰, すなわち $\log$ $i_{0 c}-1 / T$ の関係を図示したのが図 8 である。 $\log i_{0 c}-1 / T$ の関係を 直線とみなして，その勾配からニッケル析出の見かけの活性化工 ネルギーを求めた。その結果, 見かけ活性化エネルギーはニッ ケル塩濃度 $50 \mathrm{~g} / l\left(17.5 \times 10^{-5} \mathrm{~mol} / \mathrm{ml}\right), 100 \mathrm{~g} / /\left(35.0 \times 10^{-5} \mathrm{~mol} /\right.$ $\mathrm{m} l), 150 \mathrm{~g} / l\left(52.5 \times 10^{-5} \mathrm{~mol} / \mathrm{m} l\right)$ の浴で，それぞれ 8. 85, 8.03, 6. $31 \mathrm{kcal} / \mathrm{mol}$ となった。

このように見かけの活性化エネルギーはニッケル塩濃度の増加

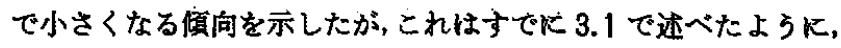
ニッケル塩濃度の高い浴中での 2 価のニッケルイオンの真の濃度 は溶解したニッケル塩蕞度よりる低いだめで、したがってニッケ ル塩の高濃度における真の活性化エネルギーは上記の值よりる大 きくなると考えられる。

- 2 価の銅イオンが 1 傅の銅イオンを経て電析する場合の活性化 エネルギーはトリフルオロ酢酸銅ーホルムアミド浴からの銅電析 に拈いて約 $3 \mathrm{kcal} / \mathrm{mol}^{\mathrm{8})}$ であった。この値と本実験で得られた ニッケル電析の見かけの活性化エネルギーの平均值 $7.7 \mathrm{kcal} / \mathrm{mol}$ を考光合わせると，活性化エネルギーの点からるニッタル塩ーホ ルムアミド浴からのニッケル電析反応は1価のニッケルイオンを 経てニッケルが析出するすのと考えられる。

\section{6 トリフルオロ酶酸の金属塩-ホルムアミド浴からの金属の} 電析

トリフルオロ酢酸の金属塩ーホルムアミド浴からの金属電析に 関して，単に鍋電析とニッケル電析たけから言及するのは問題で あるが，しかしつぎのような做向がみられた。

（1）ホルムアミドはトリフルオ口酢酸の金属塩をよく溶解し， この溶液中では金瑀錯イオンが北成される。 
（2） ホルムフミド浴から金属が析出するさいの $i_{0 \mathrm{c}}$ 值は水溶 癄からの揚合にくらべて大きいが，しかし，水液中で $i_{00}$ 值の 大きい金属はホルムアミド浴中でもその值が大きく，水溶没中で $i_{0 \mathrm{c}}$ 值の小さい金属はホルムアミド浴中であその值が小さい。

（3） $i_{00}$ 值が大きいと金属が析出しやすく，電析物が粗大に なりやすい29)が、ホルムアミド浴では金属錯イオンが形成される ので垂直方向の生長が阻害され，核の発生ヒン度が高くなり結晶 于の小さい平滑な電着面が得られる。

（4）ホルムアミド浴中では水溶液からの埸合よりす金属析出 の $i_{0 c}$ 値が大きく，しかす，金属の違いkよる $i_{0 c}$ 值の盖が小さ いので，我容液からは電析しにくい金属の電析を容易にする可能 性がみらけられる。

\section{4 結}

トリフルオロ酢酸ニッケルはホルムフミドによく溶解し，この 溶花は篻電性がよい。

トリフルオロ酰酸ニッケルーホルムアミド浴中では

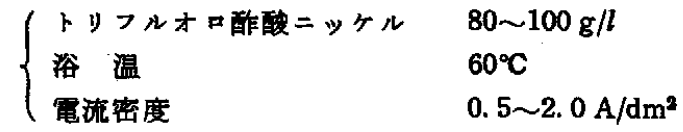

の条件で電解ニッケルメッキを行ならと萻地との密着性のよい良 好な電析物が得られる。カソード䉓流効率は約 $90 \%$ で，アノ一 ド電流效率は拉よそ100\%であり，低電流密度で得られた良好 な電着面恃非常にこまかい粒状で，電着層は粒状組織であった。

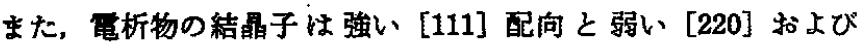
[200] 配向をしていた。そして，結晶子の大きさは 70〜80 凡 で きわめて小さい。

トリフルオロ醮酸ニッケルーホルムアミド浴中でのニッケル䉓 析反応注，電流密度 $0.9 \sim 4.8 \mathrm{~A} / \mathrm{dm}^{2}$ の範囲内で電荷移動過程が 律速になっており，見かけの通過係数 $\left(\alpha_{c}\right)$ ，見かけの価数 $(n)$, 交換電流密度 $\left(i_{00}\right)$ ，Tafel 線の勾配 $\left(b_{c}\right)$ および見かけの活性化 エネルギー $\left(E_{\mathrm{c}}\right)$ の值は拈よそつぎのようであった。

23）吉田 忠，野元成胃，電化，34，600(1966).

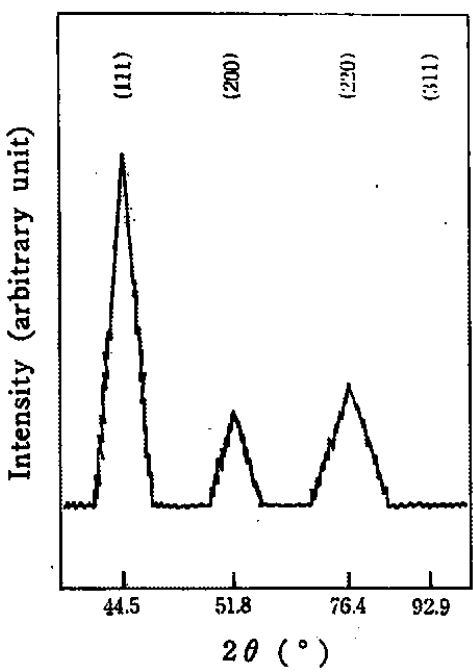

Fig. $9 \mathrm{X}$-ray diffraction pattern for nickel electrodeposit

$$
\alpha_{\mathrm{c}}=0.66
$$

すなわち $\mathrm{d} \log i_{0 \mathrm{c}} / \mathrm{d} \log C_{0}=0.34$ ，ただし $C_{0}$ は 2 俩のニッヶ ルイオン潋度である。

$n=1.00, i_{0 \mathrm{c}}=0.062 \mathrm{~A} / \mathrm{dm}^{2}, b_{\mathrm{c}}=-0.102 \mathrm{~V}, E_{\mathrm{c}}=7.7 \mathrm{kcal} / \mathrm{mol}$

これらの倠からトリフルオロ酢酸ニッケルーホルムアミド浴か らのニッケル電析反応は

$$
\begin{aligned}
& \mathrm{Ni}^{2+}+e^{-} \longrightarrow \mathrm{Ni}^{+} \\
& \mathrm{Ni}^{+}+e^{-} \longrightarrow \mathrm{Ni}^{0}
\end{aligned}
$$

のよらに進行し； 2 俩のニッケルイオンから1洒のニッケルイオ ンになる反纫が律速になっているるのと考えられる。

最後に，X線回折測定にあたり御助力いただいた信州大学工学 部の北島圆夫氏感謝の意を表します。

（1970 年 10 月，化学関係学協会中部支部連合秋季大.会発表）

\section{Electrodeposition of Nickel from $\mathrm{Ni}\left(\mathrm{CF}_{3} \mathrm{COO}\right)_{2} \cdot \mathrm{HCONH}_{2}$ Bath}

\section{Tatsuko TAKEI and Rimpei Kojima.}

The Faculty of Engineering, Shinshu University; Wakasato, Nagano-shi, Japan

This paper deals with the electrodeposition of nickel from $\mathrm{Ni}\left(\mathrm{CF}_{3} \mathrm{COO}\right)_{2}-\mathrm{HCONH}_{2}$ solutions. The properties of $\mathrm{Ni}\left(\mathrm{CF}_{8} \mathrm{COO}\right)_{2}-\mathrm{HCONH}_{2}$ bath and the mechanism of electrodeposition of nickel were studied.

Specific conductance of a $\mathrm{Ni}\left(\mathrm{CF}_{3} \mathrm{COO}\right)_{2}-\mathrm{HCONH}_{2}$ solution and apparent molecular volume of $\mathrm{Ni}\left(\mathrm{CF}_{3} \mathrm{COO}\right)_{2}-\mathrm{HCONH}_{2}$ became constant when the concentration of $\mathrm{Ni}\left(\mathrm{CF}_{3} \mathrm{COO}\right)_{2}$ was increased beyond about $200 \mathrm{~g} / l$.

There was a tendency for $\mathrm{Ni}\left(\mathrm{CF}_{3} \mathrm{COO}\right)_{2}-\mathrm{HCONH}_{2}$ solution to increase its viscosity with the increase of the concentration of $\mathrm{Ni}\left(\mathrm{CF}_{3} \mathrm{COO}\right)_{2}$.

Bright and smooth nickel deposits were obtained at a current density in the range of $0.5 \sim$ $2.0 \mathrm{~A} / \mathrm{dm}^{2}$ from $\mathrm{Ni}\left(\mathrm{CF}_{3} \mathrm{COO}\right)_{2} 80 \sim 100 \mathrm{~g} / \mathrm{HCONH}_{2} 1 l$ bath at $60^{\circ} \mathrm{C}$, the current efficiencies for cathode and anode being about $90 \%$ and $100 \%$, respectively.

The cross-section of the nickel deposits was found to have granular structure. The grain orientation was strong [111], but weak [220] and [200]. The grain size was $70 \sim 80 \AA$.

The rate of electrodeposition of nickel from $\mathrm{Ni}\left(\mathrm{CF}_{3} \mathrm{COO}\right)_{2}-\mathrm{HCONH}_{2}$ bath at a current density ranging from 0.9 to $4.8 \mathrm{~A} / \mathrm{dm}^{2}$ was controlled by a charge transfer reaction. 